\section{Mulch Improves Pecan Tree Growth during Orchard Establishment}

\author{
Michael W. Smith, Becky L. Carroll, and Becky S. Cheary \\ Department of Horticulture and Landscape Architecture, Oklahoma State \\ University, Stillwater, OK 74078
}

Additional index words. Carya illinoinensis, Carya illinoensis, fertilization, nitrogen

\begin{abstract}
Giles' pecan [Carya illinoinensis (Wangenh.) K. Koch] seedlings were either not mulched or mulched with wood chips arranged in a 1- or $2-\mathrm{m}$-wide square that was $30 \mathrm{~cm}$ deep. Mulch treatments were in factorial combination with two $\mathrm{N}$ rates applied as either a single application at budbreak or as a split application at budbreak and 3 weeks later. Tree height was positively related to mulch width each year of the 3-year study, and trunk diameter was positively related to mulch width during the second and third years of the experiment. Leaf $P$ and $K$ concentration during 2 years and leaf $N$ during 1 year of the study were positively related to mulch width. Trees receiving the higher $\mathrm{N}$ rate were taller during 2 of 3 years, but leaf $N$ concentration was not affected by $N$ rate. No differences in the parameters measured were observed whether $\mathbf{N}$ was applied as a single or as a split application.
\end{abstract}

Vegetative ground cover surrounding trees competes for nutrients (Bould and Jarrett, 1962; Goff et al., 1991; Smith et al., 1959; Worley and Carter, 1972) and water (Patterson et al., 1990; Ware and Johnson, 1958), and in some instances may be allelopathic (Friedman and Horowitz, 1970; Meissner et al., 1989; Menges, 1987; Weller et al., 1985; Wolf and Smith, 1999). Tree growth during orchard establishment can be increased by maintaining a weedfree area surrounding the tree (Foshee et al., 1995; Patterson et al., 1990; Patterson and Goff, 1994; Wolf and Smith, 1999). Cultivation (Foshee et al., 1997; Merwin et al., 1994; Patterson et al., 1990; Patterson and Goff, 1994; Smith et al., 1959), herbicides (Arnold and Aldrich, 1979; Foshee et al., 1997; Merwin et al., 1994; Norton and Storey, 1970; Patterson etal., 1990; Patterson and Goff, 1994; Robinson and O'Kennedy, 1978), or various mulch materials (Foshee et al., 1996; Merwin et al., 1994; Robinson and O'Kennedy, 1978) can be used to control weeds that interfere with growth. Cultivation is normally considered undesirable since it increases soil erosion, causes soil structure loss, and frequently results in tree injury. Herbicides have been widely accepted in modern agriculture as an effective and relatively inexpensive tool to control unwanted vegetation, but recent public concern about pesticide usage necessitates that means be sought to reduce pesticide dependency. Waste disposal facilities are being filled with materials that may be useful with minimal processing. Several municipalities are chipping tree waste, then offering it to the public free-ofcharge or even delivering truckload quantities at nearby sites to avoid land fill disposal. This material is suitable as a mulch and may offer

Received for publication 17 May 1999. Accepted for publication 9 July 1999. Approved for publication by the Oklahoma Agricultural Station, Stillwater, Okla. The cost of publishing this paper was defrayed in part by the payment of page charges. Under postal regulations, this paper therefore must be hereby marked advertisement solely to indicate this fact. certain advantages in reducing weed competition when used alone or in combination with herbicides.

Certain mulches can reduce $\mathrm{N}$ availability as they decompose (Allison, 1965), or inhibit tree growth; presumably growth-inhibiting chemicals leached from the mulch (Still et al., 1976). Foshee et al. (1996) found that mulch $30 \mathrm{~cm}$ deep was optimum for growth of young pecan trees. However, only one mulch area surrounding the trees was used in that study. Our objectives were to determine the optimum mulch area, the response of trees to $\mathrm{N}$ rate, and if a split $\mathrm{N}$ application improved tree growth in comparison with a single application when using a wood chip mulch.

\section{Materials and Methods}

One-year-old container-grown 'Peruque' pecan seedlings were planted at the Oklahoma Pecan Research Station near Perkins in Oct. 1993, spaced $10.7 \times 10.7 \mathrm{~m}$ on a Teller sandy loam (fine-loamy, mixed, thermic, Udic Argiustoll). Trees were managed according to the Oklahoma Cooperative Extension Service recommendations during establishment and while the study was in progress (Carroll et al., 1998).

A factorial treatment combination of three mulch treatments and four $\mathrm{N}$ treatments were established in Apr. 1996. The mulch treatments were $0-, 1-$, or $2-\mathrm{m}$ squares $\left(0-\mathrm{m}^{2}, 1-\mathrm{m}^{2}\right.$, or $4-\mathrm{m}^{2}$ areas) centered on the tree. All mulches were applied to a $30-\mathrm{cm}$ depth. Nitrogen rates in 1996 were 0.08 or $0.16 \mathrm{~kg} \mathrm{~N} /$ tree either applied as a single application at budbreak or one-half applied at budbreak and the other half applied 3 weeks later. The $\mathrm{N}\left(\mathrm{NH}_{4} \mathrm{NO}_{3}\right)$ was applied on one side of the tree in a band $\approx 10 \mathrm{~cm}$ wide and $60 \mathrm{~cm}$ long, $45 \mathrm{~cm}$ from the tree trunk (on top of the mulch, if present). In subsequent years the $\mathrm{N}$ rate was increased to 0.16 or 0.32 $\mathrm{kg} \mathrm{N} /$ tree (1997) and 0.23 or $0.46 \mathrm{~kg} \mathrm{~N} /$ tree (1998). The experimental design was a splitplot with mulch treatment as the main plot and
N rate and application time randomized equally as the subplots. Each treatment combination was replicated 20 times with one tree per replication.

A weed-free strip $4 \mathrm{~m}$ wide was maintained with herbicides the entire length of each tree row (including areas with mulch). Preemergent weed control was with norflurazon [4chloro-5-methylamino-2-( $\alpha$ - $\alpha, \alpha$-trifluoro-mtolyl) pyridazin-3(2H)-one], applied $\approx 2$ weeks before budbreak with a tractor-mounted boom. Simazine [6-chloro- $N, N^{\prime}$-diethyl-1,3,5-triazine-2,4-diamine] was applied during late May. Glyphosate [ $N$-(phosponomethyl)glycine] was applied with the preemergent herbicides, and as required during the growing season to maintain the rows weed-free.

The wood chip mulch originated from a local utility company as they cleared vegetation from utility right-of-ways. Typical trees included in the chips were Eastern redcedar (Juniperus virginiana L.), Bois d'arc [Osage orange; Maclura pomifera (Raf.) C. K. Schneid.], Siberian elm (Ulmus pumila L.), redbud (Cercis canadensis L.), and cottonwood (Populus deltoides Bartr. ex Marsh.). Wood chips were not composted, but were stockpiled $\approx 3$ months prior to use, and were applied to a depth of $30 \mathrm{~cm}$ only in April, and a substantial amount remained until the end of the study (3 years). Since pecan harvesters sweep the ground, the mulch must deteriorate by the time trees begin bearing ( 6 to 8 years old).

Tensiometers were installed 30 and $60 \mathrm{~cm}$ deep and $30 \mathrm{~cm}$ from the trunk of two trees per treatment. Soil tension values were recorded about three times per week during the growing season. Irrigation was applied with a traveling gun that delivered 5 to $7 \mathrm{~cm}$ of water per application, whenever tensiometers at the 30$\mathrm{cm}$ depth in the treatments without mulch averaged $-40 \mathrm{kPa}$ soil moisture tension. From 2 to $3 \mathrm{~d}$ were required to irrigate the entire plot with the traveling gun.

Leaf samples were collected during July each year using the middle pair of leaflets from the middle leaf on current-season's growth as the index tissue. In 1996, leaf samples from each treatment combination were pooled over replications to avoid excessive tree defoliation. This prevented statistical analysis of leaf elemental concentrations in 1996. In 1997 and 1998, replications were sampled individually. Leaflets were rinsed in tap water, then $2 \%$ (v/ v) P-free detergent, followed by $0.1 \mathrm{~N} \mathrm{HCl}$, and deionized water, for a total washing time not exceeding $1 \mathrm{~min}$. Leaflets were dried at $70^{\circ} \mathrm{C}$, ground to pass a 20 -mesh $(850-\mu \mathrm{m})$ screen and stored in airtight containers until analysis. Leaf elemental concentrations of $\mathrm{N}$ were determined using the macro-Kjeldahl method (Horowitz, 1980) and P was determined colorimetrically (Olsen and Sommers, 1982). Potassium, $\mathrm{Ca}, \mathrm{Mg}, \mathrm{Zn}, \mathrm{Fe}$, and $\mathrm{Mn}$ were analyzed using atomic absorption spectroscopy (model 2380; Perkin-Elmer, Norwalk, Conn.). Tree growth data, recorded during dormancy each year, included trunk diameter $(15 \mathrm{~cm}$ above the soil) and tree height measured from the soil line to the highest point on the tree. 
Data were analyzed by analysis of variance with trends calculated for mulch size. In calculating trends, the width of the mulched square $(0,1$, and $2 \mathrm{~m})$ was used as the treatment rate rather than the area mulched $\left(0,1\right.$, and $\left.4 \mathrm{~m}^{2}\right)$.

\section{Results and Discussion}

Rainfall at this site averages $894 \mathrm{~mm}$ annually, with $647 \mathrm{~mm}$ between 1 Apr. and 1 Nov. (Table 1). Annual rainfall was lower than the long-term average in 1996, and exceeded the average in 1997 and 1998. Although rainfall exceeded the 45-year average in 1998, lower than normal rainfall in May and June, and little rainfall from August through mid-September, caused severe drought stress in comparison with the other 2 years.

Prior to treatment (1995) trees were uniform in trunk diameter and tree height (Table 2). After one growing season trunk diameter was not affected by mulch treatment, but tree height was positively related to mulch width. In 1996, only one significant interaction (mulch treatment $\times \mathrm{N}$ application time) was significant in affecting trunk diameter. Time of $\mathrm{N}$ application did not affect trunk diameter if trees were not mulched or the mulch was only $1 \mathrm{~m}$ wide (data not shown). However, if the mulch was $2 \mathrm{~m}$ wide, trunk diameter was slightly larger if all the $\mathrm{N}$ was applied at budbreak rather than split between budbreak and 3 weeks later ( 28 vs. $25 \mathrm{~mm}$, respectively). In 1996, soil tension during periods of moisture stress was generally lower (less negative) at the $30-\mathrm{cm}$ depth for mulched than for nonmulched trees (Fig. 1). There were few differences in soil moisture tension at $30-\mathrm{cm}$ depth between 1- and 2-m-wide mulches, except in May, when the larger mulched area retained more soil moisture. Soil moisture tension at $60 \mathrm{~cm}$ during May and June 1996 was similar in nonmulched trees and in trees with 1-m-wide mulch. However, during the same period soil moisture tension was less when the mulch was $2 \mathrm{~m}$ wide compared with none or $1 \mathrm{~m}$ wide. During the rest of the 1996 growing season, soil moisture tension $60 \mathrm{~cm}$ deep was similar for the three mulch treatments, except for $\approx 6 \mathrm{~d}$ in September when soil moisture was depleted faster when trees were not mulched. Although stress was minimized by irrigation when soil moisture tension at the $30-\mathrm{cm}$ depth reached $-40 \mathrm{kPa}$, soil moisture was more favorable for tree growth when trees were mulched. Soil moisture fluctuated more rapidly at $30-\mathrm{cm}$ depth in nonmulched trees. At $60-\mathrm{cm}$ depth, more soil moisture was retained when the mulch was $2 \mathrm{~m}$ wide than when 0 or $1 \mathrm{~m}$ wide.

In 1997, there were no significant interactions among treatments. Trunk diameter and tree height increased with mulch size (Table 2 ). Trees without mulch were $75 \%$ larger than when the study was initiated, and those with a 2-m-wide mulched square were $146 \%$ larger after two growing seasons. Rainfall patterns were very favorable for tree growth in 1997 (Table 1). There were few periods of water stress, and none were severe enough to require irrigation (soil moisture tension $\leq-40 \mathrm{kPa}$ at
Table 1. Monthly rainfall at the Pecan Research Station, Perkins, Okla.

\begin{tabular}{lcccr}
\hline & \multicolumn{4}{c}{ Rainfall $(\mathrm{mm})$} \\
\cline { 2 - 5 } Month & 45 -year avg & 1996 & 1997 & 1998 \\
\hline January & 31 & 2 & 11 & 68 \\
February & 43 & 0 & 69 & 11 \\
March & 74 & 31 & 12 & 202 \\
April & 79 & 7 & 137 & 123 \\
May & 135 & 29 & 68 & 83 \\
June & 107 & 59 & 96 & 53 \\
July & 74 & 143 & 152 & 78 \\
August & 69 & 106 & 105 & 16 \\
September & 109 & 169 & 94 & 116 \\
October & 74 & 55 & 67 & 226 \\
November & 61 & 102 & 37 & 110 \\
December & $\underline{38}$ & 6 & 94 & 40 \\
$\quad$ Total & 894 & 709 & 942 & 1126 \\
\end{tabular}

Table 2. Main effects of mulch width and $\mathrm{N}$ rate on trunk diameter and tree height of seedling pecan trees.

\begin{tabular}{|c|c|c|c|c|c|c|c|}
\hline \multirow[b]{2}{*}{ Year } & \multicolumn{3}{|c|}{ Mulch width $(\mathrm{m})^{\mathrm{z}}$} & \multirow[b]{2}{*}{ Signif. } & \multicolumn{2}{|c|}{ N rate ${ }^{y}$} & \multirow[b]{2}{*}{ Signif } \\
\hline & 0 & 1 & 2 & & Low & High & \\
\hline \multicolumn{8}{|c|}{ Trunk diameter (mm) } \\
\hline 1995 & 11 & 11 & 10 & NS & 11 & 10 & NS \\
\hline 1996 & 16 & 17 & 18 & NS & 17 & 18 & NS \\
\hline 1997 & 21 & 23 & 26 & $\mathrm{~L}^{*}$ & 23 & 25 & $*$ \\
\hline 1998 & 33 & 38 & 40 & $\mathrm{~L}^{*}$ & 38 & 37 & NS \\
\hline \multicolumn{8}{|c|}{ Tree height $(\mathrm{cm})$} \\
\hline 1995 & 57 & 57 & 52 & NS & 56 & 55 & NS \\
\hline 1996 & 58 & 63 & 70 & $\mathrm{~L}^{*}$ & 60 & 68 & $*$ \\
\hline 1997 & 100 & 113 & 128 & $\mathrm{~L}^{*}$ & 107 & 121 & * \\
\hline 1998 & 157 & 190 & 196 & $\mathrm{~L}^{*}$ & 183 & 181 & NS \\
\hline
\end{tabular}

${ }^{2}$ Means for mulch width are pooled over $\mathrm{N}$ rate and $\mathrm{N}$ application time. Means for 80 single-tree replications. ${ }^{y}$ Low $=0.08,0.16$, and $0.23 \mathrm{~kg} \mathrm{~N} /$ tree in 1996, 1997, and 1998, respectively. High $=0.16,0.32$, and 0.46 $\mathrm{kg} \mathrm{N} /$ tree in 1996, 1997, and 1998, respectively. Means for $\mathrm{N}$ rate are pooled over mulch treatments and $\mathrm{N}$ application time. Means for 120 single-tree replications.

ss, "Nonsignificant, or the linear trend for mulch size $\left(\mathrm{L}^{*}\right)$, or $\mathrm{N}$ rates $(*)$ significantly different at $P \leq 0.05$.
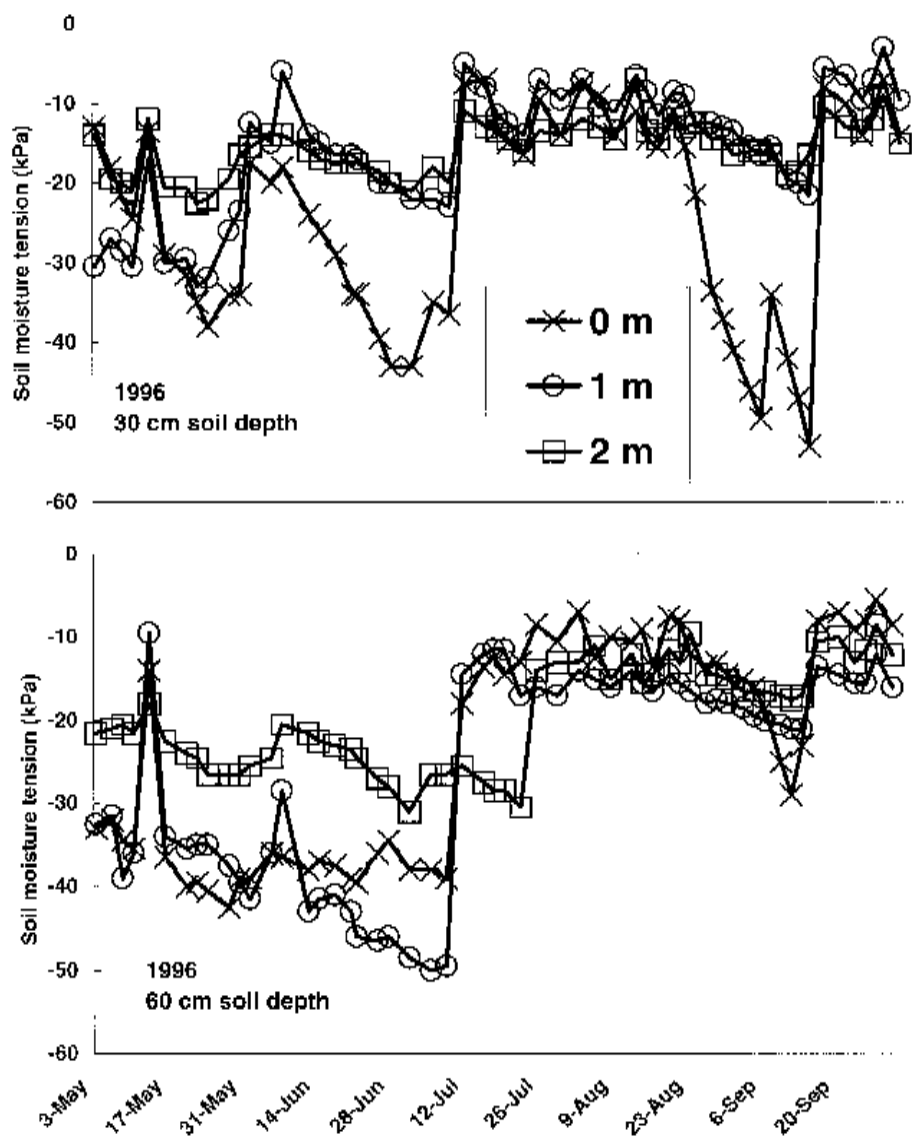

Fig. 1. The influence of mulch treatment on soil moisture tension at 30- and 60-cm depth in 1996. 
30-cm depth) (Fig. 2). Soil moisture was frequently greater at the $30-\mathrm{cm}$ level under mulched than under nonmulched trees, but differences were usually small. At $60-\mathrm{cm}$ depth, soil moisture tension was similar among mulch treatments, although nonmulched trees frequently had slightly less soil moisture. These data suggest that the slightly greater soil moisture in mulched trees may have increased growth in height. However, there were virtually no differences in soil moisture between those with a 1- vs. 2-m-wide mulch, yet those with $1 \mathrm{~m}$ of mulch grew $79 \%$ taller in year 2 and those with $2 \mathrm{~m}$ grew $82 \%$ taller. Although this is a rather small difference, it was significant. The linear increase in tree height and trunk diameter associated with mulch size may also be partially attributable to residual effects from 1996. Tree height was positively related to mulch size in 1996, and may have resulted in greater storage of nonstructural carbohydrates. This energy reserve would tend to promote more rapid growth in 1997 , even if there were few differences in soil moisture among mulch treatments.

Trunk diameter and tree height were both positively related to mulch size in 1998 (Table 2). Trees without mulch were $175 \%$ taller with $200 \%$ larger trunks, and those with mulch $2 \mathrm{~m}$ wide were $277 \%$ taller with $300 \%$ larger diameter trunks, than when the study was initiated. Rainfall during May, June, and August, extending into September, was less frequent in 1998 than in 1997, and less than the 45-year average (Table 1). Trees were irrigated several times throughout the growing season to maintain soil moisture tension at or above $-40 \mathrm{kPa}$. In fact, during late August and early September evapotranspiration exceeded our irrigation capacity (Fig. 3). Soil moisture tension data at the $60-\mathrm{cm}$ level indicated that application rates during the first part of the growing season were not sufficient to markedly increase soil moisture when trees were not mulched or mulched with a $1-\mathrm{m}$ square. Soil moisture was more favorable for growth at the $60-\mathrm{cm}$ depth using mulch $2 \mathrm{~m}$ wide, even though irrigation did not increase soil moisture to field capacity $(-10 \mathrm{kPa})$.

Mulch treatments had little effect on leaf $\mathrm{N}$ concentration in 1996 and 1997 (Table 3). In 1998 , leaf $\mathrm{N}$ was positively related to mulch area. Leaf $\mathrm{P}$ concentrations were similar among mulch treatments in 1996 , but there was a positive linear relationship with area mulched in 1997 and 1998. Increasing leaf P concentrations with mulch area may have contributed to the positive relationship observed between tree height and mulch size in 1997 and 1998 (Table 2; Sparks, 1988). Leaf K concentrations were similar in 1996, but increased linearly with mulch area in 1997 and 1998 (Table 3 ). In all cases, except for trees without mulch in 1998 , K concentrations were within normal sufficiency levels (Smith, 1991). Leaf Zn concentrations were below normal in 1996 and 1997 (Smith, 1991), although 36\% $\mathrm{ZnSO}_{4}(1.2$ $\left.\mathrm{g} \cdot \mathrm{L}^{-1}\right)$ was applied to the foliage with a handgun at 2-week intervals from budbreak until July. Visual deficiency symptoms were not present in 1996 or 1997. In 1998, the foliar Zn
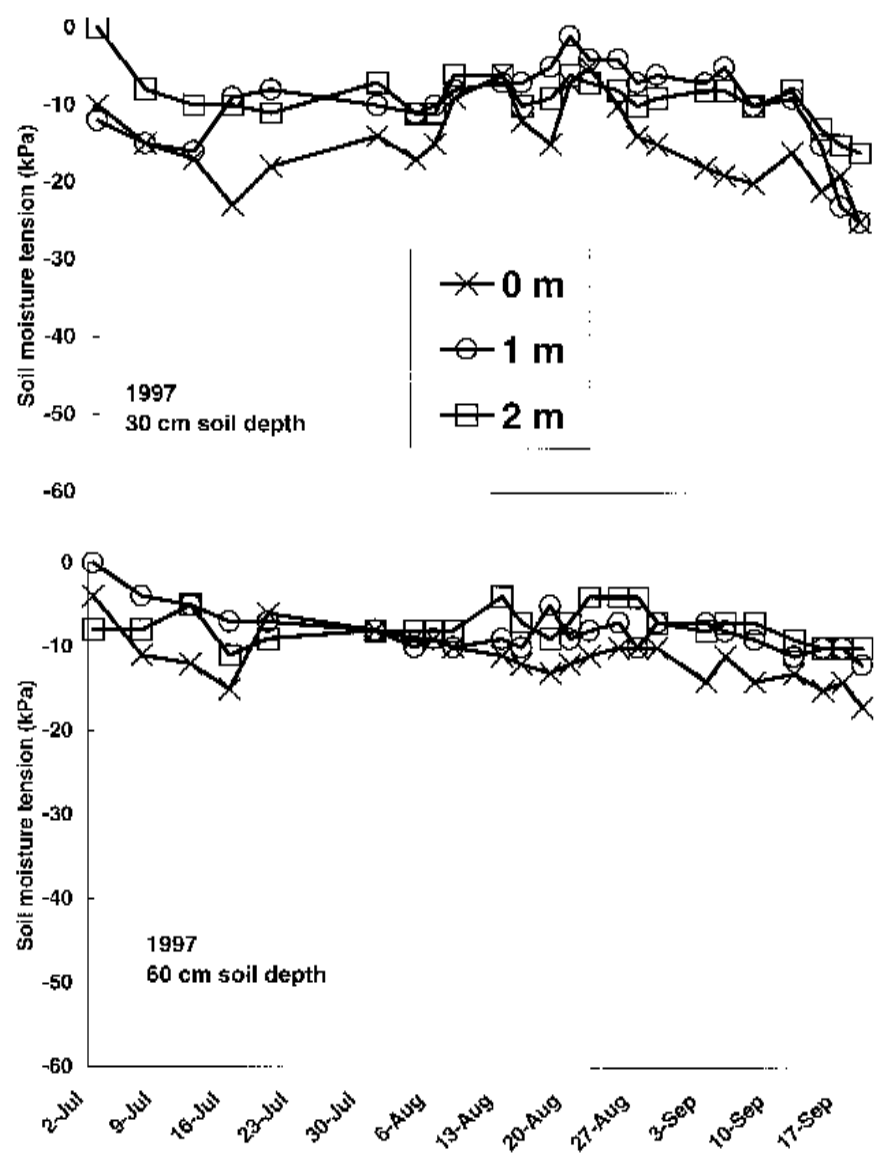

Fig. 2. The influence of mulch treatment on soil moisture tension at 30- and 60-cm depth in 1997.

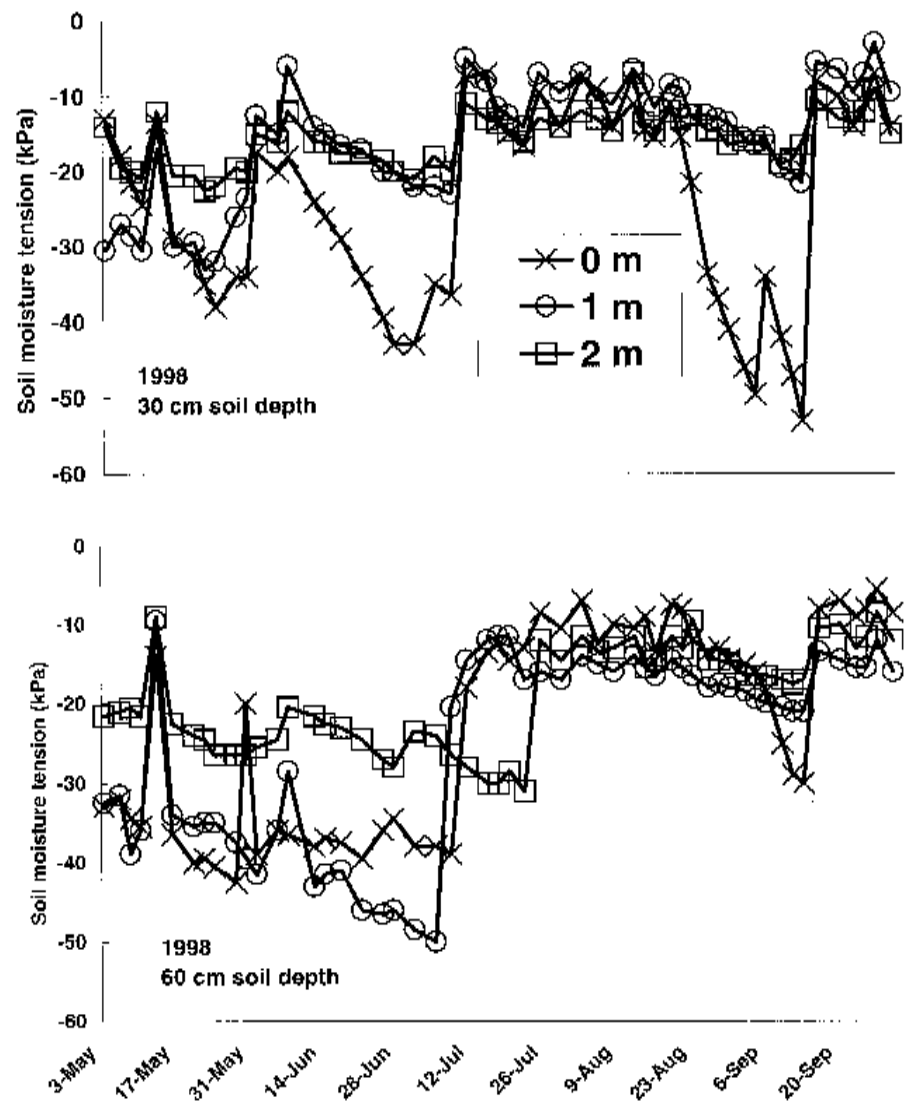

Fig. 3. The influence of mulch treatment on soil moisture tension at 30- and 60-cm depth in 1998. 
Table 3. The influence of mulch width on the leaf elemental concentration of seedling pecan trees.

\begin{tabular}{|c|c|c|c|c|c|c|c|c|}
\hline \multirow{2}{*}{$\begin{array}{l}\text { Mulch width } \\
\text { (m) }\end{array}$} & \multicolumn{5}{|c|}{ Dry wt (\%) } & \multicolumn{3}{|c|}{ Dry wt $\left(\mu g \cdot g^{-1}\right)$} \\
\hline & $\mathrm{N}$ & $\mathrm{P}$ & $\mathrm{K}$ & $\mathrm{Ca}$ & $\mathrm{Mg}$ & $\mathrm{Zn}$ & $\mathrm{Fe}$ & $\mathrm{Mn}$ \\
\hline \multicolumn{9}{|c|}{$1996^{z}$} \\
\hline 0 & 2.70 & 0.15 & 0.89 & 1.20 & 0.42 & 43 & 42 & 1185 \\
\hline 1 & 2.67 & 0.15 & 0.92 & 1.24 & 0.47 & 32 & 42 & 1014 \\
\hline 2 & 2.69 & 0.15 & 0.88 & 1.14 & 0.43 & 36 & 41 & 1135 \\
\hline \multicolumn{9}{|c|}{$1997^{y}$} \\
\hline 0 & 2.53 & 0.13 & 0.86 & 1.33 & 0.45 & 40 & 72 & 1021 \\
\hline 1 & 2.62 & 0.14 & 0.89 & 1.28 & 0.45 & 42 & 69 & 932 \\
\hline 2 & 2.58 & 0.15 & 0.98 & 1.30 & 0.44 & 39 & 80 & 1031 \\
\hline Significance & NS & $\mathrm{L}^{* * * *}$ & $\mathrm{~L}^{* *}$ & NS & NS & NS & $\mathrm{L}^{*}, \mathrm{Q}^{*}$ & NS \\
\hline \multicolumn{9}{|c|}{$1998^{y}$} \\
\hline 0 & 2.56 & 0.13 & 0.73 & 1.57 & 0.47 & 119 & 57 & 881 \\
\hline 1 & 2.65 & 0.14 & 0.81 & 1.42 & 0.45 & 109 & 58 & 708 \\
\hline 2 & 2.70 & 0.15 & 0.87 & 1.48 & 0.43 & 100 & 63 & 691 \\
\hline Significance & $\mathrm{L}^{* * *}$ & $\mathrm{~L}^{* * * *}$ & $\mathrm{~L}^{* * *}$ & NS & NS & NS & NS & NS \\
\hline
\end{tabular}

${ }^{2}$ Leaf samples pooled across replications. Data could not be analyzed.

${ }^{y}$ Means pooled across $\mathrm{N}$ rates and $\mathrm{N}$ application times. Means for 80 single-tree replications.

ws, ${ }^{*}, * * * * * *$ Nonsignificant, or the linear $(\mathrm{L})$ or quadratic $(\mathrm{Q})$ trend significant at $P \leq 0.05,0.01$, or 0.001 , respectively.

rate was doubled, resulting in normal leaf $\mathrm{Zn}$ concentration. The only other element measured that was affected by mulch treatment was iron; in 1997, there was a curvilinear increase in $\mathrm{Fe}$ associated with mulch size.

Trunk diameter was larger in 1997 and trees were taller in 1996 and 1997 when fertilized with the high rather than the low $\mathrm{N}$ rate (Table 2). However, $\mathrm{N}$ rate did not significantly affect leaf $\mathrm{N}$, and there were no significant interactions between $\mathrm{N}$ rate and mulch or $\mathrm{N}$ application time. In 1996, leaf $\mathrm{N}$ concentration averaged $2.67 \%$ for the low rate and $2.69 \%$ for the high rate. Leaf $\mathrm{N}$ concentration was $2.57 \%$ and $2.59 \%$ in 1997 , and $2.62 \%$ and $2.65 \%$ in 1998 , for the low and high rates, respectively.

Applying $\mathrm{N}$ one time at budbreak or splitting the application equally between budbreak and 3 weeks later did not affect trunk diameter, tree height, or the concentrations of any elements in the leaves (data not shown). There were no interactions between $\mathrm{N}$ application time and mulch or $\mathrm{N}$ rate for any of the variables we measured.

These data indicate that a 2-m-wide wood chip mulch applied $30 \mathrm{~cm}$ deep, combined with a 4-m-wide weed-free strip, substantially increased tree growth. Favorable soil moisture conditions were partially responsible for more growth. In addition, leaf $\mathrm{P}$ concentration was positively associated with mulch area, and probably contributed to a faster growth rate (Sparks, 1988). Although some mulches have had a negative affect on $\mathrm{N}$ availability (Allison, 1965), this mulch either had no effect or increased $\mathrm{N}$ absorption. Elimination of any weed competition in close proximity to the tree also contributes to greater tree growth (Wolf and Smith, 1999). Although trees had a 4-m-wide weed-free strip, weeds germinated near nonmulched trees and might remain up to 2 weeks before being treated with herbicide. The mulch ensured that weeds could not develop closer to the tree than the edge of the mulch. Close proximity of one or more weeds to the tree, even for a short time, probably reduced tree growth. The positive linear trends in tree height and trunk diameter with mulch width suggests that wood chip mulches wider than $2 \mathrm{~m}$ may further increase tree growth.

Trees fertilized at the high N rate were 13\% taller than those fertilized with the low $\mathrm{N}$ rate in 1996 and 1997. However, leaf N concentration did not differ significantly between treatments, and numerical differences in $\mathrm{N}$ concentration were small. Concentrations for both $\mathrm{N}$ rates during the 3 years were within the recognized sufficiency range (Smith, 1991). We cannot explain why there was more growth at the high $\mathrm{N}$ rate when there were no differences in leaf $\mathrm{N}$ concentrations.

There were no differences in any measured parameters when $\mathrm{N}$ was applied as a single or when trunk diameter of trees with mulch $2 \mathrm{~m}$ wide was larger if $\mathrm{N}$ was applied as a single rather than a split application, but trunk diameter of nonmulched trees and those with mulch $1 \mathrm{~m}$ wide was not affected by $\mathrm{N}$ application time. This indicates that leaching, volatilization, and denitrification losses were similar when $\mathrm{N}$ was applied as a single application vs. two applications 3 weeks apart. Leaching occurs when rainfall exceeds evapotranspiration for a sufficient time to cause percolation of $\mathrm{N}$ below the root zone. In Oklahoma, this normally occurs only during winter. Our first application was at budbreak, thus leaching losses would be minimized. Denitrification associated with anaerobic conditions can lead to substantial $\mathrm{N}$ losses at some pecan sites. However, at this site soils were well-drained, and not subjected to frequent anaerobic conditions that are expected in some alluvial soils located in low flood plains. Rates of $\mathrm{N}$ were not sufficiently high to negatively impact tree growth. Therefore, a single $\mathrm{N}$ application at budbreak should be used unless there are environmental constraints, such as those discussed above, that would favor a split application.

\section{Literature Cited} immature pecan (Carya illinoensis) and peach (Prunus persica) plantings. Weed Sci. 27:638-641. split application, except for one interaction

Arnold, C.E. and J.H. Aldrich. 1979. Weed control in
Allison, F.E. 1965. Decomposition of wood and bark sawdust in soil, nitrogen requirements, and effects on plants. U.S. Dept. Agr. Tech. Bul. 1332

Bould, C. and R.M. Jarrett. 1962. The effect of cover crops and NPK fertilizers on growth, crop yield and leaf nutrient status of young dessert apple trees. J. Hort. Sci. 37:58-82.

Carroll, B., M.W. Smith, and B.D. McCraw. 1998. Establishing a pecan orchard. Oklahoma Coop. Ext. Serv. F6247.

Foshee, W.G., W.D. Goff, M.G. Patterson, and D.M. Ball. 1995. Orchard floor crops reduce growth of young pecan trees. HortScience 30:979-980.

Foshee, W.G., W.D. Goff, K.M. Tilt, and J.D. Williams. 1996. Organic mulches increase growth of young pecan trees. HortScience 31:811-812.

Foshee, W.G., R.W. Goodman, M.G. Patterson, W.D. Goff, and W.A. Dozier, Jr. 1997. Weed control increases yield and economic returns from young 'Desirable' pecan trees. J. Amer. Soc. Hort. Sci. 122:588-593.

Friedman, T. and M. Horowitz. 1970. Phytotoxicity of subterranean residues of three perennial weeds. Weed Res. 10:382-385

Goff, W.D., M.G. Patterson, and M.S. West. 1991. Orchard floor management practices influence elemental concentrations in young pecan trees. HortScience 26:13791381.

Horowitz, W. 1980. Official methods of analysis of the association of analytical chemists. $13^{\text {th }}$ ed. Assn. Offic. Anal. Chemists, Washington, D.C. p. 15, section 2058.

Meissner, R., P.C. Nel, and E.A. Beyers. 1989. Allelopathic effect of Cynodon dactylon-infested soil on early growth of certain crop species. Applied Plant Sci. 3:125-126.

Menges, R.M. 1987. Allelopathic effects of Palmer amaranth (Amaranthus palmeri) and other plant residues in soil. Weed Sci. 35:339-347.

Merwin, I.A., W.C. Stiles, and H.M. vanEs. 1994. Orchard groundcover management impacts on soil physical properties. J. Amer. Soc. Hort. Sci. 119:216-222.

Norton, J.A. and J.B. Storey. 1970. Effect of herbicides on weed control and growth of pecan trees. Weed Sci. 18:522-524.

Olsen, S.R. and L.E. Sommers. 1982. Phosphorous, p. 404430. In: A.L. Page, R.H. Miller, and D.R. Keeney (eds.). Methods of soil analysis. Part 2. Chemical and microbiological properties. Amer. Soc. Agron. and Soil Sci. Soc. Amer., Madison, Wis.

Patterson, M.G. and W.D. Goff. 1994. Effects of weed control and irrigation on pecan (Carya illinoinensis) growth and yield. Weed Technol. 8:717-719.

Patterson, M.G., G. Wehtje, and W.D. Goff. 1990. Effects of weed control and irrigation on the growth of young pecans. Weed Technol. 4:892-894.

Robinson, D.W. and N.D. O'Kennedy. 1978. The effect of overall herbicide systems of soil management on the growth and yield of apple trees 'Golden Delicious'. Scientia Hort. 9:127-136.

Smith, C.L. , O.W. Harris, and H.E. Hammar. 1959. Comparative effects of clean cultivation and sod on tree growth, yield, nut quality, and leaf composition of pecan. J. Amer. Soc. Hort. Sci. 75:313-321.

Smith, M.W. 1991. Pecan nutrition, p. 152-158. In: B.W. Wood and J.A. Payne (eds.). Pecan husbandry: Challenges and opportunities. U.S. Dept. Agr., Agr. Res. Serv. ARS-96.

Sparks, D. 1988. Growth and nutritional status of pecan in response to phosphorus. J. Amer. Soc. Hort. Sci. 113:850-859.

Still, S.M., M.A. Dirr, and J.B. Gartner. 1976. Phytotoxic effects of several bark extracts on mung bean and cucumber growth. J. Amer. Soc. Hort. Sci. 101:34-37.

Ware, L.M. and W.A. Johnson. 1958. Certain relationships between fertilizer and cultural practices, nitrate and moisture content of the soil, and responses of pecan trees. Proc. Southeastern Pecan Growers Assn. 51:10 17.

Weller, S.C., W.A. Skroch, and T.J. Monaco. 1985. Common bermudagrass (Cynodon dactylon) interference in newly planted peach (Prunus persica) trees. Weed Sci. 33:50-56.

Wolf, M.E. and M.W. Smith. 1999. Cutleaf evening primrose and Palmer amaranth reduce growth of nonbearing pecan trees. HortScience 34:1082-1084.

Worley, R.E. and R.L. Carter. 1972. Effect of four management systems on parameters associated with growth and yield of pecan. J. Amer. Soc. Hort. Sci. 98:541546. 